Copyright 2012 by the Mycological Society of America. Myburg, H., Gryzenhout, M., Wingfield, B. D., Stipes, R. J. \& Wingfield, M. J. (2004). Phylogenetic relationships of Cryphonectria and Endothia species, based on DNA sequence data and morphology. Mycologia, 96(5), 990-1001. doi: 10.2307/3762083. Retrieved from: http://www.mycologia.org/content/96/5/990.abstract?sid=fd667f87-8cc4-4e30-a0c8-16b0e404253f

Mycologia, 96(5), 2004, pp. 990-1001.

(C) 2004 by The Mycological Society of America, Lawrence, KS 66044-8897

\title{
Phylogenetic relationships of Cryphonectria and Endothia species, based on DNA sequence data and morphology
}

Henrietta Myburg

Department of Genetics, Forestry and Agricultural Biotechnology Institute (FABI), University of Pretoria, Pretoria, 0002, South Africa

Marieka Gryzenhout

Department of Microbiology and Plant Pathology, Forestry and Agricultural Biotechnology Institute (FABI), University of Pretoria, Pretoria, 0002, South Africa

Brenda D. Wingfield ${ }^{1}$

Department of Genetics, Forestry and Agricultural Biotechnology Institute (FABI), University of Pretoria, Pretoria, 0002, South Africa

\section{R. Jay Stipes}

Department of Plant Pathology, Virginia Polytechnic Institute and State University, Blacksburg, Virginia 24061-0331

Michael J. Wingfield

Department of Genetics, Forestry and Agricultural Biotechnology Institute (FABI), University of Pretoria, Pretoria, 0002, South Africa

Abstract: The fungal genera Endothia and Cryphonectria include some of the most important pathogens of forest trees. Despite available new technology, no comprehensive comparative study based on DNA sequence data and morphology has been done on the available isolates representing these two genera. The main objectives of this study were to assess the phylogenetic relationships among species of Cryphonectria and Endothia, for which cultures are available, and to establish a taxonomic framework based on DNA sequence and morphological data, which will aid future studies and identification of species in these and related genera. Comparisons were based on sequence variation found in the ITS region of the ribosomal RNA operon and two regions of the $\beta$-tubulin gene. In addition, the morphology of these species was examined. The phylogenetic data indicated that Endothia and Cryphonectria reside in two distinct phylogenetic clades. Cryphonectria parasitica, C. macrospora, C. nitschkei, C. eucalypti and C. radicalis represented the Cryphonectria clade. Endothia gyrosa and

\footnotetext{
${ }^{1}$ Corresponding author. Department of Genetics, University of Pretoria, Pretoria, 0002, South Africa. Phone: +27 12420 3946. Fax: +27 12420 3947. E-mail: brenda.wingfield@fabi.up.ac.za
}

E. singularis were included in the Endothia clade. An isolate representing E. viridistroma grouped outside the Endothia clade and separately from other groups. Other clades outside the one encompassing Cryphonectria were those represented by the C. cubensis isolates and fungi isolated from Elaeocarpus dentatus originating from New Zealand. These clades could be distinguished from Endothia and Cryphonectria, based on anamorph morphology, stromatal structure and ascospore septation. Cryphonectria and Endothia, therefore, appear to be paraphyletic and taxonomic relationships for these fungi need to be revised.

Key words: $\beta$-tubulin genes, Cryphonectria, Diaporthales, Endothia, phylogeny, ribosomal DNA

\section{INTRODUCTION}

Cryphonectria and Endothia (order Diaporthales) have relatively few members but include some of the most serious pathogens of forest trees in the world. These genera have been subjected to several classical taxonomic treatments (Barr 1978, Hodges 1980, Kobayashi 1970, Roane et al 1986a, Shear et al 1917), all of which were based on morphological comparisons. Most important of these is Barr's (1978) monograph on the Diaporthales, which had a fundamental and important impact on the taxonomy of Endothia. Before the work of Barr, Cryphonectria was synonymous with the older Endothia (Kobayashi 1970, Shear et al 1917, von Höhnel 1909). Barr (1978), however, segregated Cryphonectria from Endothia based on the differences in ascospore septation and stromatal morphology. Of the 13 species originally treated in Endothia, only three were retained, i.e., E. gyrosa (Schwein. : Fr.) Fr. (type species), E. viridistroma L.E. Wehmeyer and E. singularis (H. \& B. Syd.) Shear \& N.E. Stevens. The remaining species were transferred to Cryphonectria, and these included the type species C. gyrosa (Berk. \& Broome) Sacc. (= E. tropicalis Shear \& N.E. Stevens), C. cubensis (Bruner) Hodges, C. havanensis (Bruner) M.E. Barr, C. macrospora (TakKobay \& Kaz-Itô) M.E. Barr, C. nitschkei (Otth) M.E. Barr, C. parasitica (Murrill) M.E. Barr and C. radicalis (Schwein. : Fr.) M.E. Barr. Other already described species, C. longirostris (Earle) Micales \& Stipes and $C$. coccolobii (Vizioli) Micales \& Stipes, were not mentioned by Barr (1978) but were placed in Cryphonec- 
tria by Micales and Stipes (1987) based on similarities in morphology with other species in Cryphonectria.

Of the species in Cryphonectria and Endothia, only E. gyrosa, C. parasitica, C. cubensis and the recently described C. eucalypti M. Venter \& M.J. Wingf. (Venter et al 2002) are known to be serious pathogens. The remaining members of these genera are considered saprophytic (Roane et al 1986b). Endothia gyrosa causes cankers on hardwood species in the USA and is known as the causal agent of pin oak (Quercus palustris Muench.) blight (Appel and Stipes 1986, Roane et al 1974, Snow et al 1974, Stipes and Phipps 1971). Cryphonectria parasitica is well known for the devastation that it has caused to the American chestnut, Castanea dentata Borkh. (Anagnostakis 1987, Heiniger and Rigling 1994). Cryphonectria cubensis is another important pathogen that causes a serious canker disease of plantation Eucalyptus species in tropical and subtropical areas of the world (Hodges et al 1976, 1979, Sharma et al 1985a, b, Wingfield et al 1989). This fungus also causes die-back on clove (Syzygium aromaticum [L.] Murrill \& Perry) (Myrtaceae) (Hodges et al 1986) and a serious canker disease of Tibouchina species (Melastomataceae) (Myburg et al 2002a, Wingfield et al 2001). Cryphonectria eucalypti is a canker pathogen of Eucalyptus spp. and occurs in South Africa (Gryzenhout et al 2003, van der Westhuizen et al 1993) and Australia (Old et al 1986, Walker et al 1985, Yuan and Mohammed 1997). This pathogen previously was known as E. gyrosa but was found to represent a distinct and new species (Venter et al 2001, 2002).

Endothia is characterized morphologically by strongly developed, widely erumpent stromata with predominantly pseudoparenchymatous tissue (Barr 1978, Micales and Stipes 1987). Perithecia usually are borne in an upright, diatrypoid configuration (Barr 1978, Micales and Stipes 1987). In contrast, the stromata of Cryphonectria are semi-immersed in the bark and not as strongly developed as those of Endothia (Barr 1978, Micales and Stipes 1987). Stromatic tissue is predominantly prosenchymatous, and the perithecia often are forced into a valsoid configuration by surrounding bark tissue (Barr 1978, Micales and Stipes 1987). Furthermore, Cryphonectria is distinguished by fusoid to ellipsoid, one-septate ascospores while Endothia has cylindrical to allantoid, aseptate ascospores (Barr 1978, Micales and Stipes 1987). Venter et al (2002), however, showed that ascospore septation is not the only important and supportive character for generic identification and that stromatal morphology is more useful.

It is difficult to distinguish among species of Endothia and Cryphonectria based on morphology. Distinction is restricted mainly to size differences in fruiting structures, but these often overlap (Roane 1986a, Kobayashi 1970). No method has been developed to distinguish unequivocally between all species of the two genera. Pigment production (Roane and Stipes 1978), disk electrophoresis of intramycelial enzymes (Stipes et al 1982), tolerance to antibiotics (Micales and Stipes 1986) and optimal temperatures for growth (Stipes and Ratliff 1973) could be used only to distinguish among some species, especially $C$. parasitica and E. gyrosa.

Myburg et al (1999) provided the first phylogenetic data on representatives of Endothia and Cryphonectria, while attempting to resolve taxonomic questions pertaining to C. cubensis. This study supported the conspecificity of E. eugeniae (Nutman \& Roberts) Reid \& Booth with C. cubensis and showed clearly that C. parasitica is different from E. gyrosa. Cryphonectria cubensis isolates also were found to reside in two well-resolved subclades, reflecting a South American and a southeastern Asian group. The study of Myburg et al (1999) was based on sequence variation within the ITS1 and ITS2 regions of the ribosomal RNA operon. A third subclade including isolates from South Africa was recognized when $\beta$-tubulin and histone $H 3$ gene sequences were used in phylogenetic analyses (Myburg et al 2002b).

In a phylogenetic study conducted by Venter et al (2002), additional species of Cryphonectria and Endothia were included to examine the generic placement of the new species, C. eucalypti. Isolates representing C. parasitica, C. radicalis, C. macrospora, E. gyrosa and E. singularis were included. Endothia and Cryphonectria grouped as two distinct phylogenetic clades (Venter et al 2002). Only a subset of isolates then available was used in the study of Venter et al (2002). No comprehensive study including morphology and phylogenetic data thus has been undertaken on available isolates representing the different species of these two genera. The objective of the present study, therefore, was to compare all available species of Endothia and Cryphonectria for which cultures and voucher specimens exist. More specifically, our aim was to re-evaluate the generic distinctions between Cryphonectria and Endothia and thus to provide a taxonomic basis, based on DNA sequence data and morphological characteristics, for future studies of species assemblages residing in them.

\section{MATERIALS AND METHODS}

Isolates studied.-Isolates included in this study (TABLE I) represent most of the species retained in the genera Cryphonectria and Endothia (Barr 1978, Micales and Stipes 1987). A number of these isolates were obtained from the culture collection of R.J. Stipes. Authentic cultures are not 


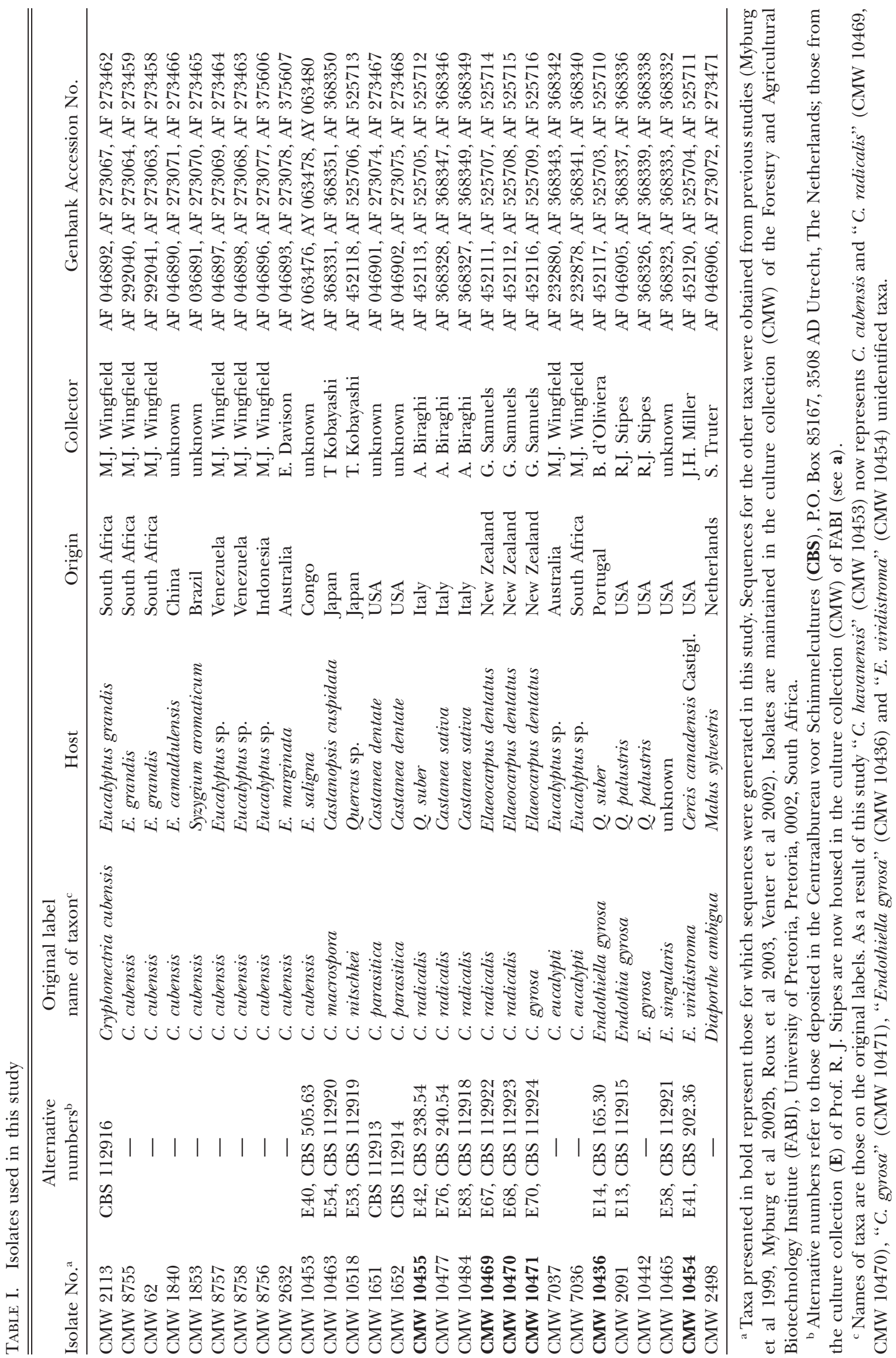


available for C. coccolobii, C. longirostris or C. havanensis, and these could not be included in this study. The C. havanensis isolate labeled as E40 (CMW 10453) in the collection of R.J. Stipes previously was found to be C. cubensis (Micales et al 1987) and not representative of C. havanensis. Isolates of C. eucalypti, the most recent addition to Cryphonectria (Venter et al 2002), also were included in this study. All isolates (TABLE I) are maintained in the culture collection (CMW) of the Forestry and Agricultural Biotechnology Institute (FABI), University of Pretoria, Pretoria, South Africa, and a duplicate set of subcultures have been deposited in the Centraalbureau voor Schimmelcultures (CBS), Utrecht, The Netherlands.

DNA extractions, ribosomal RNA (ITS1, 5.8S, ITS2) and $\beta$ tubulin gene amplification.-DNA was extracted as described by Myburg et al (1999). Amplification of the ITS 1, 5.8S and ITS 2 regions of the ribosomal RNA operon as well as two regions within the $\beta$-tubulin gene were as described by Myburg et al (1999) and Myburg et al (2002b) respectively. The primer pairs that were used to amplify the respective regions were ITS1 and ITS 4 (White et al 1990), Btla and Bt1b (Glass and Donaldson 1995) and Bt2a and Bt2b (Glass and Donaldson 1995). PCR products were purified using a QIAquick PCR Purification Kit (Qiagen GmbH, Hilden, Germany).

Ribosomal RNA (ITS1, 5.8S, ITS2) and $\beta$-tubulin gene sequencing.-PCR products were sequenced in both directions using the same primer pairs that were used in the amplification reactions. Sequencing reactions were achieved using an ABI PRISM Dye Terminator Cycle Sequencing Ready Reaction Kit with AmpliTaq ${ }^{\circledR}$ DNA Polymerase, FS (Perkin-Elmer, Warrington, United Kingdom). The nucleotide sequences were determined with an ABI PRISM $3100^{\mathbb{N} \text { au }}$ automated DNA sequencer.

Sequence alignment and analyses.-Sequence Navigator version 1.0.1 (Perkin-Elmer Applied BioSystems Inc., Foster City, California) software was used to analyse the DNA sequences. All sequences were aligned in a data matrix using Clustal X (Thompson et al 1997) and the alignment was checked manually. Sections of the ITS and the $\beta$-tubulin introns were highly variable. This resulted in difficulty when aligning sequence data. An analysis (data not shown) of only the exon regions of the $\beta$-tubulin gene produced a phylogenetic tree with a similar topology to that obtained when the full dataset was considered collectively. However, there was no resolution at the intraspecific level using this more conservative dataset and all the sequence data thus were retained in the analyses, where gaps were treated as missing data.

Subsequent phylogenetic analyses were performed using PAUP (Phylogenetic Analysis Using Parsimony) version 4.0b (Swofford 1998). A 500-replicate partition-homogeneity test (PHT) was executed to determine whether the ribosomal (ITS1, 5.8S, ITS2) and $\beta$-tubulin gene sequence datasets $(1 \mathrm{a} / 1 \mathrm{~b}, 2 \mathrm{a} / 2 \mathrm{~b})$ could be combined as one dataset before phylogenetic analyses. Gene sequences were analyzed using heuristic searches with tree-bisection-reconnection (TBR) and MulTrees option (saving all optimal trees) effective.
The confidence levels of the tree branch nodes generated in the phylogenetic analysis were determined by a $1000-$ replicate bootstrap analysis. Diaporthe ambigua Nitschke, a known canker pathogen of stone and pome fruit trees (Smit et al 1996, 1997), was included as outgroup taxon to root the phylogenetic tree. Sequences were deposited in GenBank, and the accession numbers are listed in TABLE I. The sequence alignments and phylogenetic tree (FIG. 1) were deposited in TreeBase (submission ID number $=$ SN 1205).

Morphological studies.-General morphological features, such as stromatal and spore morphology, were examined microscopically for relevant herbarium specimens of $E n$ dothia and Cryphonectria (TABLE II). As far as possible, the type specimens of the different species in the phylogenetic tree were studied. Specimens from New Zealand, linked to some of the isolates used in the phylogenetic study (TABLE II), also were included.

Fruiting structures were embedded in Leica mountant (Setpoint Premier, Johannesburg, South Africa) after rehydration in boiling water for $1 \mathrm{~min}$. Sections were made with a Leica CM1100 cryostat (Setpoint Premier) at $-20 \mathrm{C}$ and were 12-16 $\mu \mathrm{m}$ thick. Sections were dropped in water, transferred to a microscope slide, mounted in lactophenol and examined with phase contrast and differential interference contrast light microscopy.

\section{RESULTS}

Ribosomal RNA (ITS1, 5.8S, ITS2) and $\beta$-tubulin gene amplification and sequencing.-Amplification products for the respective gene regions were 550-600 bp in size (data not shown). Sequences for isolates generated in this study were aligned with sequence data from previous studies (TABLE I). The PHT performed between the ribosomal and $\beta$-tubulin gene sequence datasets generated a $P$-value of 0.01 . This indicated that there was no significant conflict between the datasets and that they could be combined in subsequent phylogenetic analyses. The ribosomal (ITS1, 5.8S, ITS2) and $\beta$-tubulin (1a/1b and 2a/2b) sequence datasets thus were analyzed together in the parsimony analyses.

The resulting combined dataset comprised 28 sequences of which one, D. ambigua, was used as outgroup taxon. A total of 1520 characters were included in the phylogenetic analyses. Of these, 942 characters were constant, 132 variable characters were parsimony uninformative and 446 variable characters were parsimony informative. No sequence characters were excluded. The heuristic search produced 23 trees, which were converted to a strict consensus tree (tree length $=1154$ steps, consistency index $=$ 0.6888 , retention index $=0.8376)$.

The consensus tree (FIG. 1) showed a well-resolved clade labeled as "Cryphonectria spp." and representing the taxa C. parasitica, C. nitschkei, C. macrospora, 


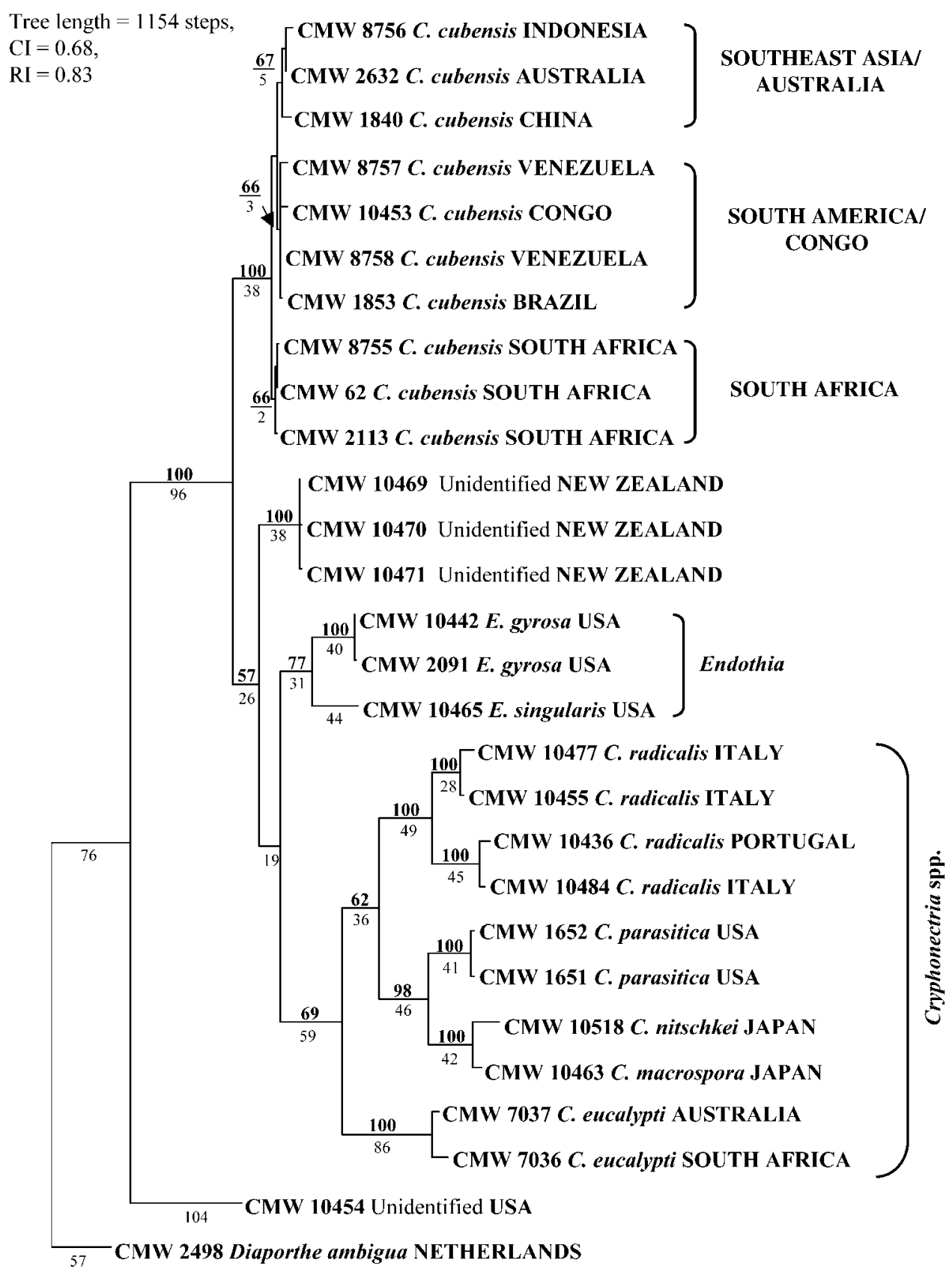

FIG. 1. A strict consensus tree (tree length $=1154$ steps, consistency index $=0.6888$, retention index $=0.8376$ ) generated from a combined dataset comprising ribosomal and $\beta$-tubulin gene sequences. Confidence levels of the tree branch nodes $(>50 \%)$ are indicated above the nodes and were determined by a 1000 replicate bootstrap analysis. Branch lengths are indicated below the nodes. Diaporthe ambigua was used as outgroup taxon.

C. eucalypti and European C. radicalis. Isolates of $C$. radicalis formed two distinct groups. One is represented by isolates CMW 10477 and CMW 10455 while the other is represented by isolate CMW 10484 and an isolate from Quercus identified as Endothiella gyrosa Sacc. (CMW 10436) (bootstrap $=100 \%$ ).

Two groups of isolates identified originally as species of Cryphonectria did not group within the main Cryphonectria clade. The first of these included un- identified isolates from New Zealand, which originally were labeled C. radicalis (CMW 10469, CMW 10470) and C. gyrosa (CMW 10471) (bootstrap support $=100 \%$ ). These isolates originated from Elaeocarpus dentatus Vahl.

The second group of isolates that clustered outside the Cryphonectria clade were those representing $C$. cubensis (bootstrap $=100 \%$ ). Within this C. cubensis sensu lato clade, the three subclades as previously de- 


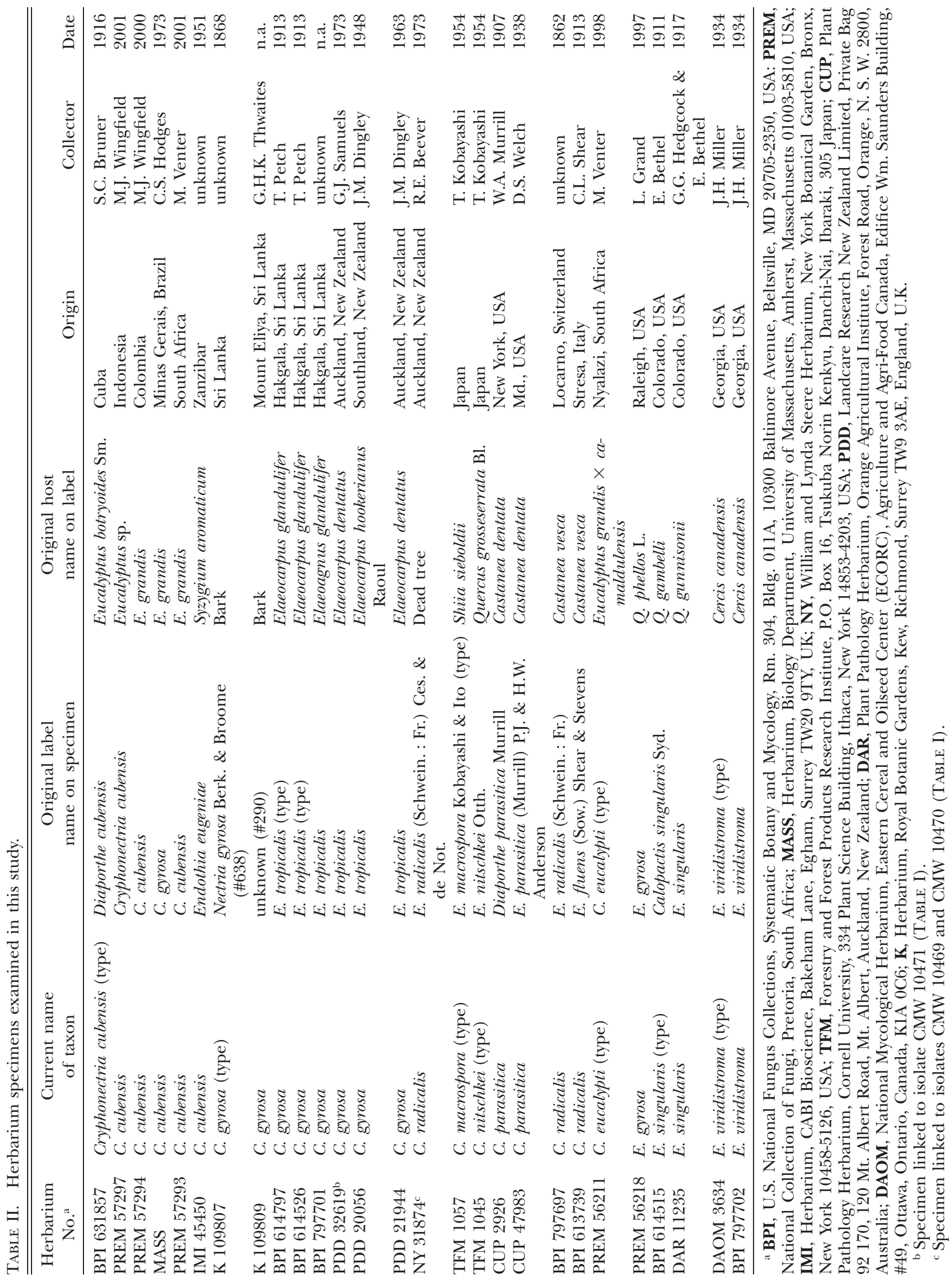




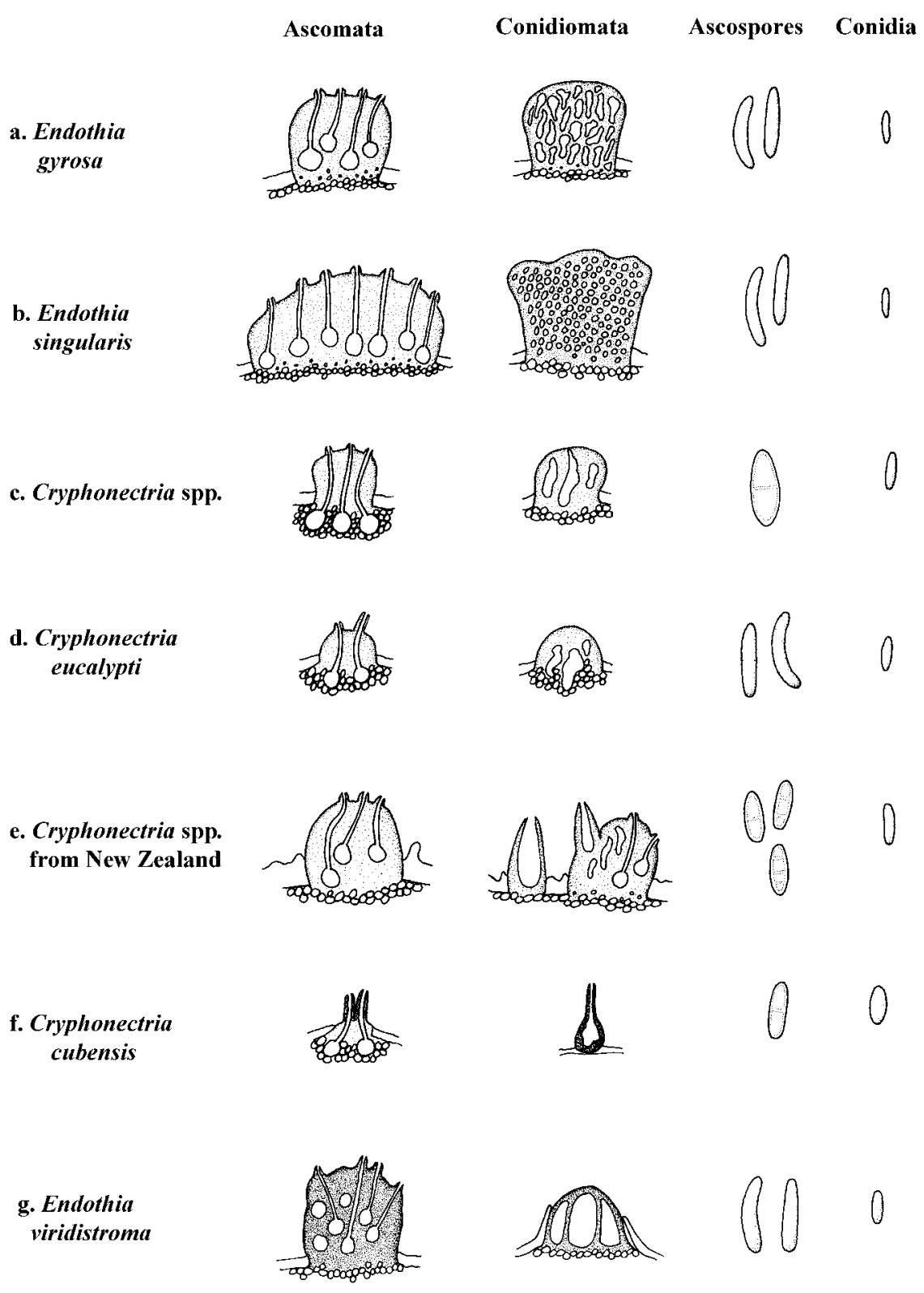

FIG. 2. Schematic drawings of the ascomata, conidiomata, ascopores and conidia of the fungi representing the different phylogenetic clades. a) Endothia gyrosa. b) Endothia singularis. c) Cryphonectria spp. representing C. parasitica, C. radicalis (Europe), C. nitschkei, C. macrospora. d) Cryphonectria eucalypti. e) Unidentified specimens labeled as C. radicalis and C. gyrosa from New Zealand. f) Cryphonectria cubensis. g) Endothia viridistroma.

fined by Myburg et al (2002b) were evident and represented C. cubensis originating from South Ameri$\mathrm{ca} /$ Congo, southeastern Asia and South Africa, respectively.

Endothia was represented by E. gyrosa and E. singularis isolates from the USA. The remaining Endoth$i$ a species, E. viridistroma, grouped separately from the Endothia and Cryphonectria clades. A BLAST search on the ITS sequence data generated for the E. viridistroma isolate revealed that it has a $97 \%$ similarity to Cytospora eucalypticola van der Westh. $($ GenBank accession number $=$ AF192321, BLAST re- sult $=835$ bits), a weak pathogen of Eucalyptus in Australia and South Africa (Old et al 1986, van der Westhuizen 1965).

Morphological studies.-The different groups found in the phylogenetic tree could be distinguished based on morphology (FIG. 2). The most important distinguishing character was anamorph morphology. The conidiomata of E. gyrosa (FIG. 2a) and E. singularis (FIG. 2b) were tuberculate and locules were numerous and minute, while those of the Cryphonectria spp. (i.e., C. parasitica, C. radicalis from Europe, C. nit- 
schkei, C. macrospora) (FIG. 2c) were pulvinate and locules were few in number and large. Those of $C$. eucalypti (Fig. 2d) were similar to those of the other Cryphonectria spp. (FIG. 2c). The conidiomata on the specimens of C. gyrosa and C. radicalis from New Zealand (FIG. 2e) were unique because single conidiomata were ovoid, superficial and unilocular. More complex conidiomatal structures on the New Zealand specimens (containing more than one ovoid structure) were multilocular with irregular conidial locules (FIG. 2e). Conidiomata of C. cubensis (FIG. 2f) also were different and generally were unilocular, superficial and pyriform with attenuated necks. The conidiomata of $C$. cubensis were blackened, unlike the orange conidiomata of other species of Cryphonectria and Endothia.

The ascomata of E. gyrosa (FIG. 2a), E. singularis (Fig. 2b) and the New Zealand specimens (FIG. 2e) were erumpent to superficial and strongly developed. Perithecia were diatrypoid and the bases situated in fungal tissue above the level of the bark. The ascomata of the Cryphonectria spp. (FIG. 2c) and C.eucalypti (FIG. 2d) also were erumpent but were semiimmersed and perithecia were valsoid, with the bases surrounded by bark tissue beneath the level of the bark. Ascomata of C. cubensis specimens (FIG. 2f) had weak to no stromatal tissue development, and the black perithecial necks, as they protruded through the stromatal surface, were covered with brown tissue, which was different from the black necks of the other specimens of Cryphonectria that were covered with orange tissue.

Ascospores of E. gyrosa (Fig. 2a) and E. singularis (FIG. 2b) were aseptate and cylindrical to allantoid. Those of the Cryphonectria spp. (FIG. 2c) and C.cubensis (FIG. 2f) were one-septate and ellipsoid to fusoid. The specimens (K 109807, K 109809, BPI 614797, BPI 614526, BPI 797701) connected to the type species of Cryphonectria, C. gyrosa from Sri Lan$\mathrm{ka}$, also had single-septate ascospores, although a few ascospores were seen with two septa. Cryphonectria eucalypti (FIG. 2d) had aseptate, cylindrical to allantoid ascospores that were different from those of other Cryphonectria species and more similar to those of Endothia species. For specimens representing the New Zealand clade (FIG. 2e), ascospores were different from those of Cryphonectria species and C. cubensis in having 1-3 septa. Conidia of E. gyrosa (FIG. 2a), E. singularis (FIG. 2b), the Cryphonectria species (Fig. 2c), C. eucalypti (FIG. 2d) and the specimens from New Zealand (FIG. 2e) were aseptate, minute and cylindrical. The conidia of C. cubensis (FIG. 2f) differed from those of the others in being more oval than cylindrical.

Features of E. viridistroma that led to its placement in Endothia are the large, erumpent, tuberculate, superficial stromata (FIG. 2g). Perithecia have a similar orientation in the stroma to those of E. gyrosa (FIG. $2 \mathrm{~g}$ ), and conidial locules are numerous and irregular to ellipsoid (Fig. 2g) (Wehmeyer 1936). Ascospores are aseptate and allantoid to slightly ellipsoid, and conidia are aseptate, cylindrical to allantoid (FIG. 2g) (Wehmeyer 1936). Endothia viridistroma, however, is atypical of all the other species of Endothia and Cryphonectria because the stromata of this species are dark green to black.

\section{DISCUSSION}

This study presents a phylogenetic analysis of a large group of isolates that were accommodated in Cryphonectria and the closely related genus Endothia. The majority of these are linked to voucher specimens representing species of Cryphonectria and Endothia, e.g., C. parasitica, C. radicalis (Europe), C. nitschkei, C. macrospora, C. eucalypti, E. gyrosa and E. singularis. Sequence and morphological data provide evidence that Endothia and Cryphonectria represent separate genera. These data also show that C. cubensis should be excluded from Cryphonectria. Similarly, taxa labeled as Cryphonectria spp., occurring on Elaeocarpus dentatus from New Zealand, do not reside in Cryphonectria and the taxon representing E. viridistroma does not belong in Endothia. Studies including more specimens and isolates for each phylogenetic group now should be undertaken to describe formally the new generic groups proposed in this study. For instance, the relationships between the three phylogenetic subclades within C. cubensis sensu lato should be clarified. The sequence and morphological data that now are available also should facilitate future segregation among species in these genera.

To the best of our knowledge, all species for which cultures currently are available were included in this study. It is unfortunate that isolates of $C$. longirostris, C. coccolobii and an authentic isolate of C. havanensis from Cuba, the described origin of $C$. havanensis (Bruner 1916), are unavailable. An isolate (CMW 10471) that originally was identified as $C$. gyrosa, isolated from specimen PDD 32619, phylogenetically and morphologically was linked to the New Zealand group studied. This isolate most probably was identified as this species due to similarities in stromatal morphology and ascospore size and the fact that it was isolated from Eleaocarpus spp. (Roane 1986a, Shear et al 1917). It seems unlikely that this specimen (CMW 10471) represents the type species of Cryphonectria, and it will be impossible to resolve this question in the absence of isolates for C. gyrosa from Sri Lanka. 
Numerous challenges exist regarding the type species of Endothia and Cryphonectria. Endothia gyrosa (Fries 1849) and C. gyrosa (Berkeley and Broome 1875) were described in the 19th century, and no cultures exist that can be linked to these names. The type specimen of $E$. gyrosa has been separated and moved among a number of herbarium collections in the past (Shear et al 1917). The only remaining fragment of the original type material of $E$. gyrosa, which was designated as a cotype by Shear et al (1917), contains only conidiomata (Shear et al 1917). Comparisons of teleomorph morphology using the current collections thus are impossible, and efforts to designate an epitype or neotype for Endothia will prove invaluable for future studies.

In the case of $C$. gyrosa, ambiguities include the existence of two sets of herbarium specimens that are linked to this fungus. The first (type specimen $\mathrm{K}$ 109807 , K 109809) is connected to the original description of C. gyrosa (basionym Diatrype gyrosa Berk. \& Broome) from Sri Lanka and the host was specified only as "sticks". Shear et al (1917) obtained an alternative set of specimens, presumably of the same fungus, from Sri Lanka (BPI 614526, BPI 614797) on Elaeocarpus glandulifer Mast., when they transferred C. gyrosa to E. tropicalis. This was after Cryphonectria had been reduced to synonymy with Endothia (von Höhnel 1909) and the new name, E. tropicalis, was given because the name $E$. gyros $a$ already existed. These BPI specimens (BPI 614526, BPI 614797) thus were designated as the type specimens of E. tropicalis (Shear et al 1917), while one of the original specimens connected to the 1875 description of $C$. gyrosa (K 109809, designated originally as No. 290) was mentioned only as an additional collection examined (Shear et al 1917). The original type specimen (K 109807) of the protologue of C. gyrosa, however, will take priority to serve as type specimen for this species (ICBN section 7.4, Greuter et al 2000).

In subsequent reviews on the taxonomy of C. gyrosa, hosts other than Elaeocarpus glandulifer have been mentioned. These include an Elaeagnus sp. (Barr 1978), as well as Elaeocarpus dentatus, Myrsine salicina Heward, several Quercus spp., Quintinia serrata A. Cunn. and Shiia sieboldii Makino (Roane 1986a). Barr (1978) also examined a specimen from Eucalyptus grandis Sm. in Brazil (MASS) for her treatment of C. gyrosa, but this specimen actually represents C. cubensis (TABLE II). The review of C. gyrosa by Barr (1978) stated that the fungus originally was described from Sri Lanka on Elaeagnus glandulifer and this possibly was based on specimen BPI 797701 that is stated to have occurred on the original host Elaeagnus glandulifer and was collected from the same locality (i.e., Hakgala, Sri Lanka) as BPI 614526 and BPI 614797. However, never has there been a plant species with the name Elaeagnus glandulifer (International Plant Name Index Query, http:// www.ipni.org/ipni/query_ipni.html) and the host for the above-mentioned material given on the herbarium packet probably should have been Elaeocarpus glandulifer. Mention of C. gyrosa on Quercus spp. and S. sieboldii (Roane 1986a) possibly originated from reports of this fungus from Japan (Kobayashi and Ito 1956, Kobayashi 1970). Quintinia serrata and M. salicina, however, are not mentioned as hosts of C. gyrosa in Japan (Kobayashi and Ito 1956, Kobayashi 1970) and the source of these reports is unclear. These contradictions regarding the appropriate type specimen for C. gyrosa need to be addressed and probably will rely on new collections from the original collection sites.

Isolates from New Zealand considered in this study and labeled as C. radicalis and C. gyrosa were not related to C. radicalis isolates or other Cryphonectria spp. within the Cryphonectria clade. These isolates from New Zealand also were not similar to the group accommodating C. cubensis or the phyloclade representing Endothia. Ascospores of the New Zealand specimens were one to three septate (FIG. 2e) and are different from species residing in Cryphonectria that have two-celled ascospores (Barr 1978). The different ascospore morphology, the ovoid anamorph structures and the phylogenetic grouping of these isolates separately from other Cryphonectria and Endothia isolates in the phylogenetic analysis suggest that they most likely represent a discrete genus.

Ascospores of specimens linked to the type species, C. gyrosa from Sri Lanka (K 109807, K 109809, BPI 614797, BPI 614526, BPI 797701), occasionally contained two septa and, therefore, were similar to specimens connected to the fungus in the New Zealand phyloclade. This type of septation never has been noted previously for C. gyrosa or for Cryphonectria (Barr 1978, Berkeley and Broome 1875, Saccardo 1905). In the absence of authentic isolates of C. gyrosa from Sri Lanka, it is impossible to tell whether this fungus will reside in the phyloclade that represents Cryphonectria in the current study. It equally could be possible that C. gyrosa will group separately from all other species of Cryphonectria. Ascospore septation observed for C. gyrosa in this study is similar to that of the New Zealand specimens, and these two fungi could represent the same taxon. This would have important consequences for the taxonomy of Cryphonectria species and their appropriate generic placement.

Our phylogenetic and morphological results provide added evidence that $C$. cubensis represents a distinct genus closely related to Cryphonectria and En- 
dothia. Isolates of C. cubensis formed a distinct group separate from other Cryphonectria spp. The dark, superficial to slightly immersed, pyriform anamorphs of C. cubensis (Bruner 1917, Hodges 1980, Myburg et al 2002b), reduced stromatic development and blackened protruding perithecial necks (Hodges 1980, Myburg et al 2003), furthermore distinguished C. cubensis from the Cryphonectria spp., the Endothia spp., the unidentified species occurring on Elaeocarpus dentatus from New Zealand and the type specimen of C. gyrosa from Sri Lanka. The morphological features that distinguish C. cubensis from Cryphonectria were evident on a variety of host genera, including clove and Eucalyptus spp.

The distinct morphology of C. cubensis, when compared with that of other Cryphonectria species, has led to uncertainty as to where C. cubensis, previously known as Diaporthe cubensis Bruner, should be placed (Bruner 1917, Hodges 1980). It has been suggested that $C$. cubensis could belong in the genus Cryptodiaporthe, with a Cystosporella anamorph (Roane 1986a). Recent phylogenetic studies based on LSU rDNA, however, showed that $C$. cubensis does not group with other Cryptodiaporthe species (Castlebury et al 2002, Zhang and Blackwell 2001). One species of Cryptodiaporthe, C. corni (Wehm.) Petr., however, did group close to C. cubensis but was not representative of the genus Cryptodiaporthe (Castlebury et al 2002, Zhang and Blackwell 2001).

Isolates labeled as C. radicalis from Europe formed two subgroups within the greater Cryphonectria clade. The one subclade (CMW 10477, CMW 10455) presumably represents $C$. radicalis, but the identity of isolates in the other subclade (CMW 10436, CMW 10484) is unknown. Cryphonectria radicalis has been reported to occur widely in Europe (Anagnostakis 1983, Hoegger et al 2002, Shear et al 1917) and in the USA (Shear et al 1917) and Japan (Kobayashi 1970). Despite this fact, few isolates exist and it reportedly is difficult to find the fungus in the United States (M. Milgroom pers comm). This might be due to its displacement by the virulent $C$. parasitica that previously was not present in its natural habitat (Anagnostakis 1983, Hoegger et al 2002). An alternative hypothesis is that $C$. radicalis is not easily noticed due to the presence of the more commonly found and pathogenic C. parasitica (Hoegger et al 2002). The correct taxonomic placement of isolates in the two subclades representing C. radicalis from Europe currently is impossible because no herbarium specimens are linked to European isolates of C. radicalis.

An isolate labeled as Endothiella gyrosa from Portugal (CMW 10436), grouped within the European C. radicalis clade. Endothiella is currently the recognized anamorph genus for both Endothia and Cry- phonectria (Hawksworth et al 1995). This specimen was isolated from Quercus suber L., the same host as that of the Italian C. radicalis isolates. We believe that this isolate was misidentified and should have been designated as C. radicalis. This illustrates the difficulty of identifying species of Endothia and Cryphonectria in the absence of teleomorph specimens. Conidia of these two genera are similar, and stromatal morphology of Cryphonectria species sometimes can be superficial and strongly developed, similar to those of E. gyrosa. This could be due to host tissue characteristics and environmental conditions (Cannon 1988, Hodges et al 1986, Shear et al 1917).

The ascospores of C. eucalypti differ from those of other Cryphonectria spp. in being aseptate. In this study, isolates of this fungus grouped most closely with Cryphonectria species and not close to those in the Endothia clade. This finding supports a previous report (Venter et al 2002) that stromatal structure is an important taxonomic feature for this group of fungi. Ascospore septation, however, has been one of the criteria with which to define the phyloclade from New Zealand. This raises the question whether the aseptate ascospores of C. eucalypti, in contrast to septated ascospores of other Cryphonectria species, suggest that this fungus represents a distinct genus from Cryphonectria. Currently available phylogenetic data provide no evidence to support transferring C.eucalypti to a discrete genus. Inclusion of larger numbers of isolates of C. eucalypti from South Africa and Australia might help to resolve this question.

The E. viridistroma specimens included in this study have green stromata (Roane 1986a, Wehmeyer 1936), unlike other species of Endothia that have orange stromata (Barr 1978, Roane 1986a, Shear et al 1917). Results of a BLAST search on the ITS ribosomal sequence data generated for this $E$. viridistro$m a$ isolate, showed sequence similarities with Cytospora eucalypticola. Endothia viridistroma, however, has large, widely erumpent, pulvinate stromata with diatrypoid perithecia (Roane 1986a, Wehmeyer 1936). This is in contrast to the immersed, typically valsoid, blackened stromata of Valsa species and their multilocular Cytospora anamorphs (Spielman 1984). It therefore is unlikely that $E$. viridistroma could be accommodated in Valsa. We believe that the E. viridistroma isolate in our collection was misidentified and does not represent the fungus originally described as E. viridistroma. The taxonomic relationships of E. viridistroma will be difficult to resolve because no other isolates of this species exist and herbarium specimens contain insufficient stromatal tissue for a meaningful taxonomic study.

The results of this study reflect the importance of linking isolates to voucher herbarium material to 
identify the defined taxa. The genera Cryphonectria and Endothia include important fungal pathogens, and it is essential that these species be identified correctly. One such example relates to $C$. cubensis sensu lato. Results of the present study and that of Myburg et al (2002b) indicate that C. cubensis sensu lato includes isolates reflecting three geographically distinctive groups. Of these, the South African C. cubensis isolates are different from C. cubensis in other parts of the world, with regard to disease symptoms (Myburg et al 2002b; Wingfield et al 1989, 2001) and the occurrence of the sexual state (Myburg et al 2002a; Wingfield et al 1989, 2001). The South African fungus is also more pathogenic than that occurring on Eucalyptus elsewhere in the world (Roux et al 2003). This discovery has important implications for the global security of Eucalyptus species, both in their native range and in countries where these trees are grown commercially. Further studies and possibly the development of rapid techniques to identify these fungi thus should be undertaken.

\section{ACKNOWLEDGMENTS}

We are grateful to colleagues and many herbaria for loans of specimens and for providing cultures used in this study. We also thank two anonymous reviewers of a previous version of this manuscript for helpful suggestions. Dr Hugh F. Glen of the National Botanical Institute of Pretoria also provided helpful advice on nomenclatural issues. This study was supported by grants from the National Research Foundation (NRF), members of the Tree Pathology Co-operative Programme (TPCP) and the THRIP support program of the Department of Trade and Industry, South Africa.

\section{LITERATURE CITED}

Anagnostakis SL. 1983. Quest for an Endothia. Bull British Mycol Soc 17:147.

- 1987. Chestnut Blight: the classical problem of an introduced pathogen. Mycologia 79:23-37.

Appel DN, Stipes RJ. 1986. A description of declining and blighted pin oaks in eastern Virginia. J Arboric 12:155158.

Barr ME. 1978. The Diaporthales in North America with emphasis on Gnomonia and its segregates. Mycol Mem No. 7. Lehre, Germany: J. Cramer Publisher.

Berkeley MJ, Broome CE. 1875. Enumeration of the fungi of Ceylon. J Linn Soc 14:29-140.

Bruner SC. 1916. A new species of Endothia. Mycologia 8: 239-242.

—. 1917. Una enfermedad gangrenosa de los eucaliptos. Estacion Experimental Agronomica, Bolletin 37:133. Santiago de las Vegas, Cuba.

Cannon PF. 1988. Proposal to merge the Phyllachorales with the Diaporthales, with a new family structure. Systema Ascomycetum 7:23-43.
Castlebury LA, Rossman AY, Jaklitsch WJ, Vasilyeva LN. 2002. A preliminary overview of the Diaporthales based on large subunit nuclear ribosomal DNA sequences. Mycologia 94:1017-1031.

Fries EM. 1849. Summa Vegetabilium Scandinaviae. Holmiae \& Lipsiae, Uppsala. p 385-386.

Glass NL, Donaldson GC. 1995. Development of primer sets designed for use with the PCR to amplify conserved genes from filamentous ascomycetes. Appl Environm Microbiol 61:1323-1330.

Greuter W, McNeill J, Barrie FR, Burdet HM, Demoulin V, Filgueiras TS, Nicolson DH, Silva PC, Skog JE, Trehane P, Turland NJ, Hawksworth DL. 2000. International Code of Botanical Nomenclature (Saint Louis Code). XVI International Botanical Congress, St. Louis, Missouri, July-August 2000. Königstein, Germany: Koeltz Scientific Books. 389 p.

Gryzenhout M, Eisenberg BE, Coutinho TA, Wingfield BD, Wingfield MJ. 2003. Pathogenicity of Cryphonectria eucalypti to Eucalyptus clones in South Africa. For Ecol Manag 176:427-437.

Hawksworth DL, Kirk PM, Sutton BC, Pegler DN. 1995. Ainsworth \& Bisby's dictionary of the fungi, 8th ed. reprinted. Oxford, United Kingdom: CAB International. $186 \mathrm{p}$.

Heiniger U, Rigling D. 1994. Biological control of chestnut blight in Europe. Annu Rev Phytopathol 32:581-599.

Hodges CS. 1980. The taxonomy of Diaporthe cubensis. Mycologia 72:542-548.

— Cryphonectria cubensis and Endothia eugeniae. Mycologia 78:334-350.

, Geary TF, Cordell CE. 1979. The occurrence of Diaporthe cubensis on Eucalyptus in Florida, Hawaii and Puerto Rico. Pl Dis Rep 63:216-220.

— Reis MS, Ferreira FA, Henfling JDM. 1976. O cancro do eucalipto causado por Diaporthe cubensis. Fitopatologia Brasileira 1:129-162.

Hoegger PJ, Rigling D, Holdenrieder O, Heiniger U. 2002. Cryphonectria radicalis: rediscovery of a lost fungus. Mycologia 94:105-115.

Kobayashi T. 1970. Taxonomic studies of Japanese Diaporthaceae with special reference to their life histories. Bull Gov For Exp St 226:132-147.

- Ito K. 1956. Notes on the genus Endothia in Japan I. Species of Endothia collected in Japan. Bull Gov For Exp St 92:81-98.

Micales JA, Stipes RJ. 1986. The differentiation of Endothia and Cryphonectria species by exposure to selected fungitoxicants. Mycotaxon 26:99-117.

-1 - 1987. A reexamination of the fungal genera Cryphonectria and Endothia. Phytopathology 77:650654.

- - - Bonde MR. 1987. On the conspecificity of Endothia eugeniae and Cryphonectria cubensis. Mycologia 79:707-720.

Myburg H, Gryzenhout M, Heath R, Roux J, Wingfield BD, Wingfield MJ. 2002a. Cryphonectria canker on Tibouchina in South Africa. Mycol Res 106:1299-1306. , Wingfield BD, Wingfield MJ. 2002b. $\beta$-tu- 
bulin and Histone $H 3$ gene sequences distinguish Cryphonectria cubensis from South Africa, Asia and South America. Can J Bot 80:590-596.

2003. Conspecificity of $\mathrm{En}$ dothia eugeniae and Cryphonectria cubensis: a re-evaluation based on morphology and DNA sequence data. Mycoscience 44:187-196.

—, Wingfield BD, Wingfield MJ. 1999. Phylogeny of Cryphonectria cubensis and allied species inferred from DNA analysis. Mycologia 91:243-250.

Old KM, Murray DIL, Kile GA, Simpson J, Malafant KWJ. 1986. The pathology of fungi isolated from eucalypt cankers in south-eastern Australia. Austr For Res 16:2136.

Roane MK. 1986a. Taxonomy of the genus Endothia. In: Roane MK, Griffin GJ, Elkins JR, eds. Chestnut blight, other Endothia diseases, and the genus Endothia. St. Paul, Minnesota, USA: APS Press. p. 28-39.

- 1986b. Other diseases caused by Endothia species. In: Roane MK, Griffin GJ, Elkins JR, eds. Chestnut blight, other Endothia diseases, and the genus Endothia. St. Paul, Minnesota, USA: APS Press. p. 27. - Stipes RJ. 1978. Pigments in the fungal genus Endothia. Virginia J Sci 29:137-141.

— - , Phipps PM, Miller Jr OK. 1974. Endothia gyrosa, causal pathogen of pin oak blight. Mycologia 66:1042-1047.

Roux J, Myburg H, Wingfield BD, Wingfield MJ. 2003. Biological and phylogenetic analyses suggest that two Cryphonectria spp. cause cankers of Eucalyptus in Africa. Pl Dis 87:1329-1332.

Saccardo PA. 1905. Sylloge Fungorum 42:783-781. Patavii.

Sharma JK, Mohanan C, Florence EJM. 1985a. Disease survey in nurseries and plantations of forest tree species grown in Kerala. KFRI Research Report 36. Kerala Forest Research Institute, Kerala, India. 1985b. Occurrence of Cryphonectria canker disease of Eucalyptus in Kerala, India. Ann Appl Biol 106:265-276.

Shear CL, Stevens NE, Tiller RJ. 1917. Endothia parasitica and related species. US Dept Agric Bull 380:1-82.

Smit WA, Viljoen CD, Wingfield BD, Wingfield MJ, Calitz FJ. 1996. A new canker disease of apple, pear, and plum rootstocks caused by Diaporthe ambigua in South Africa. Pl Dis 80:1331-1335.

—, Wingfield BD, Wingfield MJ. 1997. Vegetative incompatibility in Diaporthe ambigua. Pl Pathol 46:366372.

Snow GA, Beland JW, Czabator FJ. 1974. Formosan sweetgum susceptible to North American Endothia gyrosa. Phytopathology 64:602-605.

Spielman LJ. 1984. A monograph of Valsa on hardwoods in North America. Can J Bot 63:1355-1378.

Stipes RJ, Emert GH, Brown RD Jr. 1982. Differentiation of Endothia gyrosa and Endothia parasitica by disc electro- phoresis of intramycelial enzymes and proteins. Mycologia 74:138-141.

- Phipps PM. 1971. A species of Endothia associated with a canker disease of pin oak (Quercus palustris) in Virginia. Pl Dis Rep 55:467-469.

— growth of Endothia gyrosa and E. parasitica. Virginia J Sci 24:136 (abstract).

Swofford DL. 1998. PAUP*4.0. Phylogenetic analysis using parsimony (*and other methods). Sunderland, Massachusetts: Sinauer Associates.

Thompson JD, Gibson TJ, Plewniak F, Jeanmougin F, Higgins DG. 1997. The Clustal X windows interface: flexible strategies for multiple sequence alignment aided by quality analysis tools. Nucl Acids Res 25:4876-4882.

van der Westhuizen GCA. 1965. Cytospora eucalypticola sp. nov. on Eucalyptus saligna from northern Transvaal. Suid Afrikaanse Bosboutydskrif 54:8-11.

van der Westhuizen IP, Wingfield MJ, Kemp GHJ, Swart WJ. 1993. First report of the canker pathogen Endothia gyrosa on Eucalyptus in South Africa. Pl Pathol 42:661663.

Venter M, Myburg H, Wingfield BD, Coutinho TA, Wingfield MJ. 2002. A new species of Cryphonectria from South Africa and Australia, pathogenic to Eucalyptus. Sydowia 54:98-117.

von Höhnel F. 1909. Fragmente zur Mykologie. XV. Mitteilung, Nr. 407 bis 467. In Math Naturw Kl, Abt 1, Bd 118, Heft 9. Vienna: Sitzber, K Akad Wiss. p. 14611552, 1 illus.

, Wingfield MJ, Coutinho TA, Wingfield BD. 2001. Molecular characterization of Endothia gyrosa isolates from Eucalyptus in South Africa and Australia. Pl Pathol 50:211-217.

Walker J, Old KM, Murray DIL. 1985. Endothia gyrosa on Eucalyptus in Australia with notes on some other species of Endothia and Cryphonectria. Mycotaxon 23:353370 .

White TJ, Bruns T, Lee S, Taylor J. 1990. Amplification and direct sequencing of fungal ribosomal RNA genes for phylogenetics. In: Innis MA, Gelfand DH, Sninsky SS, White TJ, eds. PCR protocols: a guide to methods and applications. San Diego, California: Academic Press, Inc. p 315-322.

Wingfield MJ, Rodas C, Wright J, Myburg H, Venter M, Wingfield BD. 2001. First report of Cryphonectria canker on Tibouchina in Colombia. For Pathol 31:1-10.

— Swart WJ, Abear B. 1989. First record of Cryphonectria canker of Eucalyptus in South Africa. Phytophylactica 21:311-313.

Wehmeyer LE. 1936. Cultural studies of three new Pyrenomycetes. Mycologia 28:35-46.

Yuan ZQ, Mohammed C. 1997. Investigation of fungi associated with stem cankers of eucalypts in Tasmania, Australia. Australas Pl Pathol 26:78-84.

Zhang N, Blackwell M. 2001. Molecular phylogeny of dogwood anthracnose fungus (Discula destructiva) and the Diaporthales. Mycologia 93:355-365. 